\title{
Linking Scientific Literacy, Scientific Argumentation, and Democratic Citizenship
}

\author{
Ozden Sengul \\ Department of Mathematics and Science Education, Faculty of Education, Boğaziçi University, Turkey
}

Copyright $\subseteq 2019$ by authors, all rights reserved. Authors agree that this article remains permanently open access under the terms of the Creative Commons Attribution License 4.0 International License

\begin{abstract}
Argumentation can develop individuals' epistemologies to acknowledge the multiplicity of the ideas and propose, justify, and evaluate the knowledge claims by coordinating them with appropriate evidence. This paper aims to examine how and why argumentation should be incorporated into science instruction addressing various contexts to promote student learning, active engagement, and democratic citizenship. In particular, the socio-scientific contexts can enhance learners' scientific literacy, scientific reasoning, critical thinking, and knowledge of the nature of science about complex scientific issues related to the political, economic, and social aspect of the society. This paper argues for the relationship between scientific literacy, scientific argumentation, and socio-scientific issues to enhance students' thinking about societal problems. The paper examines the historical perspectives related to science teaching and learning and the concept of scientific literacy and addresses the significance of scientific argumentation to promote learners' engagement in the scientific processes and democratic citizenship.
\end{abstract}

Keywords Scientific Literacy, Argumentation, Democratic Education, Citizenship

\section{Introduction}

In recent years, science educators and researchers have directed the focus of the central goal of teaching and learning science towards improving learners' higher-order thinking and engagement in a debate about a scientific issue related to their lives (Rudolp \& Horibe, 2016). Explicit calls for these aims were made in the national science education documents (American Association of the Advancement of Science [AAAS], 1994; National Research Council [NRC], 2012). The milestone document focusing on scientific literacy, Benchmarks for Scientific Literacy (AAAS, 1994), addressed that science education should empower learners to develop understandings and habits of mind and make decisions in "building and protecting a society, which is open, decent, and vital" ( $p$. xiii). This national report aimed to create a society that is just and secure and has economic vitality through the character and quality of its education (AAAS, 1994).

In another document, Taking Science to School, Duschl, Schweingruber, and Shouse (2007) argued that learning science could develop learners' abilities to engage in scientific investigations and improve their problem-solving skills in science classrooms, which, in turn, could lead them to make decisions about science-related issues and develop their technical and scientific abilities as educated citizens. This report addressed that citizens should learn and experience how to contribute to the civil, social, and political issues in the society and engage in scientific conversations to address social justice in the science classrooms (Emdin, 2011). Similarly, A Framework for K-12 Science Education (NRC, 2012) and a subsequent document, Next Generation Science Standards (NGSS Leads States, 2013), suggested that science education should educate diverse students in science and engineering with the foundational scientific knowledge that they can become critical consumers of science through making evaluative judgments of the scientific claims and evidence-based explanations.

These national science education documents (e.g. AAAS, 1994; NRC, 2012) recommended that learners' engagement in the practical work of science such as extended investigations and explanations based on evidence could enhance their scientific literacy and promote their decision-making about science-related public issues and democratic citizenship (Rudolp \& Horibe, 2016). Considering these recommendations, this paper aims to examine how and why Engaging in argument from evidence (NGSS Lead States, 2013) as a core scientific practice can be a good approach for democratic education. This article provides a brief analysis of science teaching and learning through argumentation and its relation to democratic education and the development of the concept of scientific literacy in the society. The paper also explains how scientific literacy and argumentation can help 
individuals think beyond the classroom science and become critical thinkers and decision makers about scientific issues within the society.

While preparing the current review, the author searched for the representative peer-reviewed literature using the Web of Science, ERIC, and Google Scholar databases (2005-2018) to determine the journal articles, books, and book chapters related to science teaching and learning, scientific literacy, teaching and learning through argumentation, and democratic citizenship. This paper focuses on the historical approaches in science teaching and learning (e.g. Dewey, 1910; Schwab, 1962), the suggestions of national science education reform documents (e.g. NGSS Lead States; NRC, 2012), and recent work on argumentation in science education and democratic education (2005-2018). In particular, the author included the chapters published in these books: Adelson (2017), Matthews (2014), Peters (2017), Apple (2014), Postman (2011), and Basu, Bartu, and Tan (2011). As noted earlier, the main areas addressed in this paper include "Science teaching and learning, examining the concept of scientific literacy, teaching and learning through argumentation, and the relationship between scientific argumentation and democratic citizenship.”

\section{Science Teaching and Learning}

Historically, science was defined as a body of knowledge that was constructed through a universal method of formulating hypotheses and verifying them through experimentation by the rote procedures (NRC, 2012). These procedures encourage science teachers and learners to simply follow steps and learn science as true facts instead of thinking about the possibility of alternative views (Schwarz \& Baker, 2016; Windschitl, Thomson, \& Braaten, 2008). However, many scholars have criticized the approach to science as a certain and objective knowledge (e.g. Dewey, 1910; Hadzigeorgiou, 2015; Vesterinen, Tolppanen, \& Aksela, 2016). Dewey (1910) emphasized the concept of questioning as fundamental thinking and reflective thought in the method of inquiry. Dewey's pragmatic approach was opposed to the positivistic view and aimed to deal with public related problems in a continuous process of practical and productive reasoning (Turnbull, 2008). John Dewey's ideas emphasized the conception of scientific thinking and scientific inquiry. In How We Think $(1910,1933)$ and Democracy and Education (1916), Dewey addressed the indispensable traits of reflective thinking through the definition of problem, noting conditions associated with the problem, formulating a hypothesis for solving the problem, elaborating the value of various responses, and testing the ideas to see which method could provide the best solution for the problem. Dewey thought that through engaging in these experiences, learners could develop their ability to make informed decisions based on the empirical evidence (Levinson, 2010).
Similarly, Schwab (1962) approached teaching science as an "enquiry into enquiry" (p. 65) that emphasized students' engagement of process of discovery through debates, experimentation in diverse methods, and interpretation of results rather than "rhetoric of conclusions" (p. 24). Schwab supported the active process of inquiry that guided through existing theories or conceptions and exploration to resolve the scientific problems rather than objective truths. Then, Kuhn (1970) in Structure of Scientific Revolutions provided a paradigmatic shift in the philosophy of science, in which "inductivist and falsificationist accounts of science were challenged" ( $p$. 107). Kuhn (1970) focused on the revolutionary character of scientific progress and argued that one method could be replaced with another one in the process of science involving both theoretical and empirical work from a relativist perspective (Sankey, 2016). Moreover, deriving out of an epistemological perspective, Irzik and Nola (2014) argued that differences in the aspects of science could be incorporated together in a systematic way to promote conscience and expression. The researchers thought that it was necessary to accept the validity or legitimacy of alternative systems of knowledge and ideas through critique and refinement in line with the social and ethical norms. Irzik and Nola (2014) also suggested that an open-ended nature of science approach with methodological pluralism could acknowledge the existence of different epistemic perspectives to make, produce, and teach science through critical discussion.

The alternative epistemological approaches to teaching and learning science require learners' enculturation into the practices of scientific community that they can design scientific investigations involving data collection, analysis, verification, construction of evidence-based explanations (Berland et al., 2016; Osborne, 2014). In other words, they can engage in argument from evidence and come to understand "how scientists establish credibility for the claims" (Osborne, 2014, p. 180). Learners' involvement in the investigative process can empower them to understand the implications and issues related to the developments in science and technology and make informed decisions about these issues in the society (Manz, 2014). Therefore, preparing learners to become scientifically literate can develop their knowledge and ability in science content, scientific writing, and reading. They can also apply their understandings into real-life events, become active participants as responsible citizens, and enhance critical thinking and moral character.

\section{Examining the Concept of Scientific Literacy}

Dewey (1929) argued that the progressive education movement could bring a significant change in the life conditions of the classrooms, and stated, 
For the creation of a democratic society, we need an educational system where the process of moral and intellectual development is in practice as well as in theory a cooperative transaction of inquiry engaged in by free, independent human beings, who treat ideas and the heritage of the past as means and methods for the further enrichment of life, quantitatively and qualitatively, who use the good attained for the discovery and establishment of something better (p. 84).

Dewey supported the establishment of democratic society through an education system addressing the development of knowledge in a continuous exploration process through collaboration. However, despite the suggestions of progressive educators, science education had been struggling with the shortcomings of traditional instruction, teacher shortages, low teacher salaries, poorly qualified teachers, and large class sizes (Adelson, 2017). The decisions made about national security, economic growth, as well as political issues have influenced the pathways and support for educational programs in the United States since the 1950s with the launch of the Sputnik orbiting satellite (Lundgren, 2017). Americans realized the results of neglecting science, mathematics, and language after the Sputnik, and strived for the establishment of new technology to be competitive in science and technology in the world (Anderson, 2007; Kelly, 2017). The public education system in United States needed to address the issues related to economic exploitation, gender, and diversity that formed the socio-economic context in schools to improve science education (Murry, 2017).

The aims of scientific literacy were established as to prepare citizens for careers in technical operations and to provide a general science education background required for productive citizenship (Yacoubian, 2018). In 1960s, Schwab (1962) emphasized the process of construction of scientific knowledge as priority, in which the interpretations of facts were the results of the process of inquiry. Schwab made a case for "teaching science as enquiry" including "a treatment of scientific knowledge in terms of its origins in the united activities of human mind and hand which produce it; it is a means for clarifying and illuminating scientific knowledge" (p.102) rather than the "existence of a universal method or logic" (p. 24). Schwab argued that individuals should know that science was a product of enquiry or a mode of investigation involving discovery, uncertainty, and failure. Rather than learning the facts, individuals' engagement in the scientific investigations and discussions about problems, data, and the role of technology were emphasized as a way of helping them develop methods to generate reliable knowledge and make informed evidence-based conclusions related to public issues.

During the first decade of the $21^{\text {st }}$ century, the idea of using content standards to define what learners should know in science and to organize curriculum and assessment around those statements became a widely accepted approach in the improvement of science education. In 2007, the Carnegie Corporation of New York and the American Institute established a Commission on Mathematics and Science Education for Advanced Study. The Commission worked on its 2009 report entitled, The Opportunity Equation: Transforming Mathematics and Science Education for Citizenship and the Global Economy (2009). The report suggested that educational efforts should focus on the advancement of instructional strategies, curriculum materials, and teacher education programs addressing the essential ideals that all students should know. The purpose of the report was parallel to the aim of the knowledge-based economy to prepare individuals through a model of education for lifelong learning, which can engage them in the dialect about social, political, and economic issues in the social context (World Bank Group, 2017). Following this suggestion from the Carnegie Commission on Mathematics and Science Education, a Committee on a Conceptual Framework for New K-12 Science Education Standards was formed at the National Research Council to address the developments in teaching and learning science and suggested,

Being a critical consumer of science and the products of engineering, whether as a lay citizen or a practicing scientist or an engineer, also requires the ability to read or view reports about science in the press or on the Internet and to recognize the salient science, identify sources of error and methodological flaws, and distinguish observations from inferences, arguments from explanations, and claims from evidence. All of these are constructs learned from engaging in a critical discourse around texts. (NRC, 2012, p.75)

The NRC framework served to guide the development of the Next Generation Science Standards (NGSS) (NGSS Lead States, 2013), which was organized around learning performance statements to combine disciplinary knowledge and knowledge of crosscutting content, aspects of nature of science, and science and engineering practices (NGSS Lead States, 2013). Students' enculturation into the process of science was considered to help them move toward a more integrated and coherent approach in teaching and learning science. Next, the PISA framework for 2015 (OECD, 2012) aimed to incorporate epistemic knowledge as consisting of two components- (a) knowledge of the constructs and defining features essential to the process of knowledge building in science and (b) the role of constructs in justifying the knowledge produced by science (Pena-Lopez, 2012). These documents emphasized that students needed to recognize the multiplicity of views and engage in not only merely stating what they know but also support their claims with appropriate evidence and explain the rationale for their evidence. These reform efforts aimed to help students comprehend science content, be aware of the scientific approach to inquiry, and understand science as a social enterprise regarding the broad goals of science 
education. Science courses had been involved in the curriculum to develop individuals, who would attend to either a science- or non-science majors and their abilities to learn science as a way of examining the world as well as to understand the nature, importance of science and its linkage to real-life and public issues.

The parameters in scientific literacy are broad and aim to help the public learn about science and scientific enterprise in different ways including everyday applications, technology, reading and writing in science, and viewing science study as a career path and as an intellectual activity. Individuals should have sufficient knowledge to read and write as a significant part of science education and fundamental sense of literacy, which requires comprehension, interpretation, analysis, construction, and critique of scientific issues (National Academies of Sciences, Engineering, and Medicine [NASEM], 2016). In addition, scientific literacy is an understanding of science and requires not only the application of distinct components of science, but also the ability of accurate interpretation and construction of science-based ideas (Cavagnetto, 2010). Teaching practices, the curriculum materials, and learning environments should provide students opportunities to engage in critical thinking and discourse to understand the dynamic relationship between science and technology in the society and their impact on the development of scientific knowledge and problem-solving skills.

In summary, the understanding of scientific literacy is open-ended and ever changing. The fundamental goal of science education becomes to develop scientific literacy through creating individuals that enhance public interest and understanding towards scientific issues (NASEM, 2016; NRC, 2012). Individuals should enhance not only the knowledge of physical, biological, or chemical facts, but also should engage in critical thinking about science and understand what counts as science and how science differs from non-science, how to participate in science-related social issues, and the risks and benefits of science (Yacubian, 2018). Scientific literacy is the term that has been commonly used to illustrate this vision of science education, which aims to "contribute to the development of 'informed citizenry' so that students will be able to participate in decision-making about personal and political issues that have a scientific dimension" (Vesterinen et al., 2016 , p. 32). Scientific literacy focuses on more than understanding and applying scientific concepts and requires "the integration of scientific ideas, metacognitive processes, critical reasoning skills, and cultural aspects of science" (Cavagnetto, 2010, p. 337). Scientific literacy also addresses science as a social process concerning citizenship, decision-making, and democratic participation (Rudolph \& Horibe, 2016). Learning science has been described as a process of inquiry to help students develop an extensive knowledge of the procedures required to produce new scientific knowledge as a socially negotiated and culturally-embedded product. In this process, individuals need to understand a variety of complex scientific, social, and economic constructs to feel the social responsibility.

\section{Teaching and Learning through Argumentation}

Scientific argumentation is considered as a significant component of scientific literacy (Cavagnetto, 2010) that supports students' engagement in authentic science learning through the construction, evaluation, and refinement of scientific claims via diversity of methods, practices, ways of reasoning, and reflective participation (Ford, 2015). Students also need to understand the epistemic goals- "how and why the natural world works in the ways it does" (Berland et al., 2016, p. 1085) in the process of generating evidence-based explanatory models through designing investigations, collecting and analyzing data, and engaging in argumentation in a collaborative group activity (Osborne, 2010). Their engagement in this core practice of science can promote students' participation in cognitive, social, and epistemic aspects of scientific thinking and reasoning to support their understanding of how knowledge is developed in the scientific community (Jimenez-Aleixandre \& Crujeiras, 2017; Osborne, 2010). These aspects of scientific argumentation can develop citizens who are critically-minded, who can analyze and challenge social structures, and who can participate in the social construction of the society through diverse modes of communication.

Ford (2012) made the case for the scientific sense-making through engaging in the roles of both a constructor and critique: constructing a scientific claim and conducting an experiment to present the claim with evidence-based explanations to the community of peers and debating with other scientists about the alternative ideas and relevancy of the claims to eliminate the errors in the practice and make revisions. Scientific claims are accepted by the community of scientists when everyone in the community reaches a consensus about the claims. This process indicates that scientists engage in the grasp of practice not merely through an individual effort but also through the dialectic between construction and critique of knowledge claims (Ford, 2008a, 2008b). This kind of a practice may promote learners' enculturation into both social and individual sense-making processes and understanding of how basic scientific endeavor works (Ford, 2012).

As a fundamental aspect of scientific literacy, learners' engagement in argumentation can support the development of writing and talking in the language of science through defending their claims and persuasion. According to Lehrer and Schauble (2015), scientific discourse activities include learners' assessment of the alternative claims, weighing 
evidence, interpreting texts, and evaluating the validity of the scientific claims in the process of argumentation. Learners engage in the construction of knowledge claims and exchange and critique of their ideas based on the evidence (Ford, 2012). In this kind of social context, students' reasoning becomes public, and they are expected to back up their statements with evidence and evaluate alternative ideas. Through developing communicative competencies, they can reflect on their own experiences and ideas about the science and society, share their understandings with others, and transform their ideas through critique rather than accepting the power (Albe \& Gombert, 2012; Barrue \& Albe, 2013).

Teaching science through argumentation helps students understand the socially constructed nature of scientific knowledge as they discuss the legitimacy of their claims through social interactions. Students can have the opportunity to persuade their peers to accept an assertion or answer in the process of solving a conflict or problem through argumentation (Berland \& Reiser, 2010). If students participate in a social debate in science classrooms about scientific concepts, they can understand both cognitive social and epistemic aspects of knowledge construction. Science curriculum should support students' learning through addressing the role of science in society to promote their personal or political decision-making about issues related to science, technology, and society such as global climate change or genetic testing. If reform-based science education supports the integration of more learner-centered approaches and the inclusion of issues related to science and technology, how and why can scientific argumentation be an effective strategy for democratic participation? The next section will discuss the role of scientific argumentation in promoting democratic citizenship.

\section{Science Education, Scientific Argumentation, and Democratic Citizenship}

A democratic society aims to discover community values for its members through collaborative deliberation without unrestricted majority rule (Gutmann, 1999; Knowles \& Clark, 2018). Recent policy documents of science education (e.g. NGSS Lead States, 2013; NRC, 2012) have the central goal to prepare the next generation to develop a knowledge base to understand the science-related issues that they will encounter in their daily lives as citizens (Rudolp \& Horibe, 2016). How can science education help citizens understand the good and productive relationship between the intellectual and social role of science in the society? Engaging students in teacher-centered instruction provided limited opportunities for learners to become consumers of knowledge and resulted in memorization of facts without understanding why they are learning or without making justifications for their knowledge claims. In this type of instruction, teachers had the autonomy and authority both positionally and intellectually to direct the classroom activities and transfer the knowledge (Postman, 2011). Instead, in democratic education, a teacher should share the authority with the student through creating a learning process continuous and interactive and enhancing student voice in science classrooms (Basu, Barton, \& Tan, 2011; Knowles \& Clark, 2018).

Dewey $(1916,1929)$ argued that a specific focus on the science content as a product paid particular attention to the accumulation of knowledge through transfer of the information. He criticized the traditional methods of teaching science and supported the science teaching and learning as an iterative and dynamic process, in which learners continuously modified and expanded their knowledge through the methods of inquiry. According to Dewey (1929),

Science signified the existence of systematic methods of inquiry, which, when they are brought to bear on a range of facts, enable us to understand them better and to control them more intelligently, less haphazardly and with less routine (p. 8-9).

He suggested that as an alternative to the perspective of science as merely a body of knowledge or conceptual content to increase students' standardized test scores, science education aims to introduce science as a method of inquiry. Learners should engage in the process of science through communicating, generating, and interpreting scientific explanations based on evidence (Berland et al., 2016).

Learners' participation in sophisticated and scientifically authentic inquiry activities can engage them in the methods and applications of science in a real-life context. However, these technologically-oriented projects may only encourage students to manipulate the structures or to complete the task without an understanding of abstract scientific concepts (Levinson, 2010; Rudolph, 2005). This aspect of science instruction emphasizes the engineering problem of education related to framing science learning solely as a mechanical skill (Postman, 2011). Recent national documents on science education (e.g. NASEM, 2016; NRC, 2012) aim to enhance public understanding of the nature of science. They suggested that science was beyond simply classroom instruction; science education should also address students' cultural practices, families and communities (O'Neill, 2011). Science education should be embedded in the out-of-school activities besides the formal science education (NRC, 2012). Science and science teaching require an intellectual focus to understand how the engineering activities should engage students in authentic science experiences through constructing and testing hypothesis and interpreting the findings collaboratively (Schraw, Crippen, \& Hartley, 2006). Learners should move away from thinking science as a mere technical approach to developing scientific reasoning 
and thinking skills through using multiple methods and critical examination of the alternative ideas and addressing students' funds of knowledge.

What is the social function of science and science education in the society? Schools serve to address the democratic and economic ideals of a society. Labaree (1997) suggested that schools aim to prepare citizens with equal care to take the responsibility of competent participation and to train future workers, scientists, and engineers as skilled experts to "enhance productivity, therefore, promote economic growth" (p. 48). According to Labaree, teaching and learning science can be approached as a mechanism to promote the economic future and to invest the human capital. In a democratic society, science education serves to meet the interests of democracy by not only preparing individuals to be experts on different science disciplines as scientists but also developing their knowledge and abilities to think critically and engaging in scientific practices (Cavagnetto, 2010). It can also promote learners' engagement in a reasoned discourse to make thoughtful decisions considering democratic ideals of the society. Morever, Rudolph and Horibe (2016) argued that besides embracing the content knowledge, individuals should understand the social and epistemic aspects of science learning. What students learn about science in schools should prepare them to make connections with the science-related issues in the society. Similarly, the recent United States (US) K-12 Framework for Science Education (NRC, 2012) suggests,

By the end of the $12^{\text {th }}$ grade, students should have gained sufficient knowledge of the scientific practices, crosscutting concepts, and core ideas of science and engineering to engage in public discussions on science-related issues, to be critical consumers of scientific information related to their everyday lives. (p. 24)

The improvements in science and technology in the $21^{\text {st }}$ century aim to build students' school science learning experiences through linking the science content to lived experiences for active, democratic participation and citizenship (Albe \& Gombert, 2012; Sadler, Barab, \& Scott, 2007). In this regard, socio-scientific issues (SSI) have a central role to contribute to citizenship education (Levinson, 2010; Oulton, Dillon, \& Grace, 2004; Sadler \& Zeidler, 2005). According to Berkowitz and Simmons (2003) (as cited in Sadler et al., 2007),

Science education must serve as a foundation for the education of an informed citizenry who participate in the freedoms and powers of a modern democratic, technological society. With the rapid development of scientific knowledge and advent of new technologies, all members of society must have an understanding of the implications of that knowledge upon individuals, communities, and the global village in which we now live (p. 117).
In these reform suggestions, the notion of citizen science addresses the individuals' decision making about issues having scientific dimension in different contexts ranging from personal matters to production of scientific knowledge in the society (Hadzigeorgiou, 2015; Rudolph \& Horibe, 2016). SSIs have been utilized as a way to describe social dilemmas in science fields and to teach science content as well as to empower learners in the decision-making related to social, economic and political issues (Levinson, 2010). For example, in different studies, science lessons aimed to develop students' conceptual understanding while focusing on the socio-scientific issues such as educating children at school about the negative effects of drugs and high alcohol consumption, and using fluoride in drinking water to reduce tooth decay (Rudolph \& Horibe, 2016), the concerns related to global climate, MMR vaccinations or GMO foods (Baram-Tsabari \& Osborne, 2015), and finding methods to remove the stain from a cloth (Rudolph, 2014).

Teaching of SSIs involves complex, open-ended, and debatable problems in the social and scientific context. The use of SSIs can be a significant strategy to enhance students' scientific literacy and to make decisions about students' lived experiences (Zeidler, Applebaum, \& Sadler, 2011). SSIs promote students' active engagement during lessons to develop their interest and motivation, content knowledge, nature of science understandings, community of practice, and higher order thinking such as argumentation, critical thinking, informal reasoning, and reflective judgment (Albe \& Gombert, 2012; Karpudewan \& Roth, 2018; Zeidler \& Nichols, 2009). As one of the strategies, argumentation has been utilized as a strategy to provide opportunities for students to engage in social negotiation of controversial issues in the process of both knowledge construction, justification, and persuasion (Albe \& Gombert, 2012, Sadler et al., 2007). In a recent study, Karpudewan and Roth (2018) investigated grade-6 students' informal reasoning skills while completing tasks, which focused on urban development, water pollution, illegal hunting, illegal logging, deforestation, plastic pollution, global warming, and recycling. The results indicated that over the course of the unit, students could develop the knowledge of science concepts, construct more sophisticated arguments and rebuttals, and enhance the number of justifications in providing supportive arguments. Similarly, Sadler et al. (2007) argued that socio-scientific issues provided a context to teach science content and scientific practices because students could investigate the genetic engineering and use genetics concepts through a web-based virtual environment rather than working on closed-ended genetics questions. The authors suggested that socio-scientific reasoning could help students experience ongoing inquiry and skepticism and examine a problem from multiple perspectives that can challenge their ideas and evaluate the alternative claims through counter-claims or rebuttals. This process supports students 
to learn how to ask questions and communicate information through talking and writing in the language of science as central practices of scientific literacy. Students can improve their competency in communication and critical thinking, and their experiences in solving the social problems related to science and technology can also foster democratic citizenship.

\section{Concluding Remarks}

The education system emphasizes the monolithic view of domination through textbooks, teaching strategies, the meanings that students use to negotiate their classroom experiences, and the science content (Adelson, 2017). This form of positivist education treated knowledge as objective by misrepresenting the social, economic, and political ideals. However, educators must consider the alternatives of ideas to move forward through addressing the necessity of conflict and transformation to initiate a change. Therefore, this paper supports the integration of the controversial issues into the instruction and science curriculum to promote both teachers and students' participation in scientific discourse. Teachers need to develop the knowledge and abilities in being reflective practitioners to educate students to be active and critical citizens, who can strive for a socially, politically, and economically just society.

After the launch of Sputnik in 1950s, in United States, science education focused on the development of science curricula including concepts related to modern science with the emphasis of developing the scientific literacy. Scholars focused on learners' involvement in the process of scientific inquiry, questioning, different ways of thinking, analysis and interpretation of data, and evaluation of ideas in a collaborative work (Osborne, 2010) as well as their engagement in cognitive, epistemic, and social aspects in the construction and critique of knowledge claims (Jimenez-Aleixandre \& Crujeiras, 2017). This process in school science education required the science curriculum not only to address merely the scientific facts related to biology, chemistry or physics but also to refer to the scientific public issues or issues related to day-to-day decision-making of communities. School science education aimed to encourage students to make connections between scientific knowledge and other domains through the process of scientific argumentation including verbal, social, and rational activity to make individuals' thinking visible and support the development of scientific thinking. Therefore, the national reform documents (e.g. NGSS Lead States, 2013; NRC, 2012, 2016) supported students to develop scientific reasoning through diverse modes of communication including data collection, analysis, and argumentation about public-related issues, and move these experiences beyond the school.
Despite the efforts for changing the traditional instruction, schooling has emphasized teacher-centered instruction, in which students were passive and expected to memorize the facts to increase their test scores; students' diverse abilities were undermined (Banilower \& Gordon, 2019). However, students come to the classrooms with diverse abilities and backgrounds that influence their development and efficiency (Basu et al., 2011), and educators need to be able to develop strategies to accommodate diverse learners' needs. As Dewey (1916) suggested, schools are the places, where students experience the democratic participation. In a democratic classroom, both teachers and students have equal rights and responsibilities to shape the classroom instruction (Apple, 2014; Basu et al., 2011). Moreover, democratic citizenship is a political engagement, in which individuals need to commit to the fundamental processes of democracy to express their opinions, participate in debates, and make compromises through identification, explanation, analysis, evaluation, defending, and persuasion about public issues (Schwarz, 2009). It is crucial to emphasize the role of a classroom context involving these practices in students' lives beyond the school. Students should be given more opportunities to experience critical thinking and reflective judgment and understand the dynamic relationship between science, technology, and society and their implications.

Democratic societies can only be sustained if individuals are enabled to participate in debates in societies, in which they inhabit (Baram-Tsabari \& Osborne, 2015) Students should develop the intellectual skills and the information to enable them to think about democratic politics and to develop their deliberative skills and their knowledge through practical experience (Feinstein, 2011). Shifting the focus of science instruction from what students know to how students know and why they believe (Berland et al., 2016) requires teachers to develop strategies to address scientific controversial issues to engage students in the construction and critique of knowledge claims related to these events. Incorporating scientific argumentation into teaching and learning science can be a way of liberating education to enculturate students into the practices of scientists. In this way, students can participate in doing science and scientific discourse through taking a critical stance about controversial science issues linked to social and political literacy to promote social responsibility and student thinking on social values (Vesterinen et al., 2016). School science should enable students to make decisions in informed ways about scientific issues associated with economy, politics, environment or health to prepare them as the future members of a democratic society (Rudolph \& Horibe, 2016). School curriculum should also address the social implications of science-related issues to engage learners in the practice of argumentation and develop a critical attitude toward evaluating the relevancy of knowledge claims and sufficiency of evidence. 
In this paper, as a significant component of scientific literacy, scientific argumentation has been emphasized to be integrated into classroom instruction to enhance students' engagement in the practices of scientists through constructing evidence-based explanations, critiquing each other's explanations, and refining their explanations. It was suggested that socio-scientific issues can establish a context to learn science content, enhance learners' engagement in scientific practices, particularly argumentation, and promote democratic participation in a collaborative activity focusing on the public issues. This paper argued that despite the efforts of previous reform documents and curriculum developments, research in science education requires more attention to enhance learners' both scientific thinking or habits of mind and democratic participation through explicit focus on developing scientific literacy prerequisite to democratic citizenship. Science instruction should go beyond teaching the engineering aspect of science or merely teaching the procedures and should give more attention to social and epistemic aspect of science learning, in which learners can learn how to think critically and solve complex problems. Science instruction should focus on educating learners as democratic citizens by addressing the science content within a social context to develop their ability in making informed decisions individually or collectively.

\section{REFERENCES}

[1] Adelson, J. (2017). How the schools were ruined. In Inventing Adolescence (pp. 15-39). Routledge.

[2] Albe, V., \& Gombert, M. J. (2012). Students' communication, argumentation and knowledge in a citizens' conference on global warming. Cultural Studies of Science Education, 7(3), 659-681.

[3] American Association for the Advancement of Science [AAAS]. (1994). Benchmarks for science literacy. Oxford University Press.

[4] Anderson, R. D. (2007). Inquiry as an Organizing Theme for Science Curricula. Handbook of research on science education, 1, 807-830

[5] Apple, M. W. (2014). Official knowledge: Democratic education in a conservative age. Routledge.

[6] Banilower, E. R., \& Gordon, E. M. (2019, February). Where Are We Now? : Results from a National Study of Computer Science Teachers and Teaching. In Proceedings of the 50th ACM Technical Symposium on Computer Science Education (pp. 330-331). ACM.

[7] Baram - Tsabari, A., \& Osborne, J. (2015). Bridging science education and science communication research. Journal of Research in Science Teaching, 52(2), 135-144.

[8] Barrue, C., \& Albe, V. (2013). Citizenship education and socio-scientific issues: Implicit concept of citizenship in the curriculum, views of French middle school teachers. Science
\& Education, 22(5), 1089-1114.

[9] Basu, S. J., Barton, A. C., \& Tan, E. (Eds.). (2011). Democratic science teaching: Building the expertise to empower low-income minority youth in science (Vol. 3). Springer Science \& Business Media.

[10]Berkowitz, M. W., \& Simmons, P. E. (2003). Integrating science education and character education. In The role of moral reasoning on socio-scientific issues and discourse in science education (pp. 117-138). Springer, Dordrecht.

[11]Berland, L., \& Reiser, B.J. (2010). Classroom communities' adaptations of the practice of argumentation. Science Education, 95, 191-216. doi:10.1002/sce.20420

[12]Berland, L. K., Schwarz, C. V., Krist, C., Kenyon, L., Lo, A. S., \& Reiser, B. J. (2016). Epistemologies in practice: Making scientific practices meaningful for students. Journal of Research in Science Teaching, 53(7), 1082- 1112.

[13]Cavagnetto, A. R. (2010). Argument to Foster Scientific Literacy: A Review of Argument Interventions in K-12 Science Contexts. Review of Educational Research, 3, 336.

[14]Dewey, J. (1910). Science as subject-matter and as method. Science, 121-127.

[15]Dewey, J. (1916). Democracy and Education: An Introduction to Philisophy of Education. Macmillan.

[16]Dewey, J. (1929). The sources of a science of education. Read Books Ltd.

[17]Dewey, J. (1933). How we think. Heath \& Co Publishers.

[18]Duschl, R. A., Schweingruber, H. A. \& Shouse, A. W. (Eds.). (2007). Taking science to school: Learning and teaching science in grades $K-8$. National Academies Press.

[19]Emdin, C. (2011). Citizenship and social justice in urban science education. International Journal of Qualitative Studies in Education, 24(3), 285-301.

[20]Feinstein, N. (2011). Salvaging science literacy. Science education, 95(1), 168-185.

[21]Ford, M. (2008a). Disciplinary Authority and Accountability in Scientific Practice and Learning. Science Education, 92, 404- 423.

[22]Ford, M. (2008b). "Grasp of practice" as a reasoning resource for inquiry and nature of science under- standing. Science and Education, 17, 147-177.

[23]Ford, M. J. (2012). A dialogic account of sense-making in scientific argumentation and reasoning. Cognition and Instruction, 30(3), 207-245.

[24]Gutmann, A. (1999). Democratic education. Princeton University Press.

[25]Hadzigeorgiou, Y. (2015). A critique of science education as sociopolitical action from the perspective of liberal education. Science \& Education, 24(3), 259-280.

[26]Irzik, G., \& Nola, R. (2014). New directions for nature of science research. In International handbook of research in history, philosophy and science teaching (pp. 999-1021). Springer, Dordrecht. 
[27]Jiménez-Aleixandre, M. P., \& Crujeiras, B. (2017). Epistemic practices and scientific practices in science education. In Science Education (pp. 69-80). Sense Publishers, Rotterdam.

[28]Karpudewan, M., \& Roth, W. M. (2018). Changes in Primary Students' Informal Reasoning During an Environment-Related Curriculum on Socio-scientific Issues. International Journal of Science and Mathematics Education, 16(3), 401-419.

[29]Kelly, G. J. (2016). Inquiry Learning and Teaching in Science Education. Encyclopedia of Educational Philosophy and Theory, 1-6.

[30]Knowles, R. T., \& Clark, C. H. (2018). How common is the common good? Moving beyond idealistic notions of deliberative democracy in education. Teaching and Teacher Education, 71, 12-23.

[31]Kuhn, T. S. (1970). The structure of scientific revolutions, International Encyclopedia of Unified Science, vol. 2, no. 2.

[32]Labaree, D. F. (1997). Public goods, private goods: The American struggle over educational goals. American Educational Research Journal, 34(1), 39-81.

[33]Lehrer, R., \& Schauble, L. (2015). Learning progressions: The whole world is NOT a stage. Science Education, 99(3), 432-437.

[34]Levinson, R. (2010). Science education and democratic participation: An uneasy congruence? Studies in Science Education, 46(1), 69-119.

[35]Lundgren, U. P. (2017). Curriculum as a Governing Device. Encyclopedia of educational philosophy and theory, 339 344.

[36]Manz, E. (2014). Representing student argumentation as functionally emergent from scientific activity. Review of Educational Research, 1-38. doi: 10.3102/00346543145584 90

[37]Murry, A. T. (2017). Culturally Responsive Education: The Need and Methods for Demonstrating Effectiveness for Evidenced-based Practices. Honoring Our Teachers, 175.

[38]National Research Council. (2012). A Framework for K-12 Science Education: Practices, Crosscutting Concepts, and Core Ideas.: National Academies Press

[39]National Academies of Sciences, Engineering, and Medicine. (NASEM, 2016). Science literacy: Concepts, contexts, and consequences. National academies press.

[40]NGSS Lead States (2013). Next generation science standards: For states, by states. National Academies Press.

[41]O'Neill, T. (2011). Improvisation With/in Science. In Democratic Science Teaching (pp. 41-54). Sense Publishers.

[42]Organisation for Economic Cooperation and Development Staff. (2012). PISA 2009 technical report. OECD publishing.

[43] Osborne, J. (2010). Arguing to learn in science: The role of collaborative, critical discourse. Science, 328(5977), 463-466.

[44]Osborne, J. (2014). Scientific practices and inquiry in the science classroom. In Handbook of Research on Science Education, Volume II (pp. 593-613). Routledge.

[45]Oulton, C., Dillon, J., \& Grace, M. M. (2004). Reconceptualizing the teaching of controversial issues. International Journal of Science Education, 26(4), 411-423.

[46]Peña-López, I. (2012). PISA 2012 Assessment and Analytical Framework. Mathematics, Reading, Science, Problem Solving and Financial Literacy.

[47]Postman, N. (2011). The end of education: Redefining the value of school. Vintage.

[48]Rudolph, J. L. (2014). Dewey's "science as method" a century later: Reviving science education for civic ends. American Educational Research Journal, 51(6), 1056-1083.

[49]Rudolph, J. L., \& Horibe, S. (2016). What do we mean by science education for civic engagement? Journal of Research in Science Teaching, 53(6), 805-820.

[50]Sadler, T. D., \& Zeidler, D. L. (2005). Patterns of informal reasoning in the context of socio-scientific decision making. Journal of Research in Science Teaching, 42(1), 112-138.

[51]Sadler, T. D., Barab, S. A., \& Scott, B. (2007). What do students gain by engaging in socio-scientific inquiry? Research in Science Education, 37(4), 371-391.

[52] Sankey, H. (2016). Scientific realism and the rationality of science. Routledge.

[53] Schwab, J. J., \& Brandwein, P. F. (1962). The teaching of science: The teaching of science as enquiry (Vol. 253). Harvard University Press.

[54] Schwarz, B. B. (2009). Argumentation and learning. In Argumentation and education (pp. 91-126). Springer US.

[55]Schwarz, B. B., \& Baker, M. J. (2016). Dialogue, argumentation and education: History, theory and practice. Cambridge University Press.

[56]Schraw, G., Crippen, K. J., \& Hartley, K. (2006). Promoting self-regulation in science education: Metacognition as part of a broader perspective on learning. Research in Science Education, 36(1-2), 111-139.

[57]Vesterinen, V. M., Tolppanen, S., \& Aksela, M. (2016). Toward citizenship science education: what students do to make the world a better place? International Journal of Science Education, 38(1), 30-50.

[58]Windschitl, M., Thompson, J., \& Braaten, M. (2008). Beyond the scientific method: Model - based inquiry as a new paradigm of preference for school science investigations. Science Education, 92(5), 941-967.

[59] World Bank Group. (2017). World Development Indicators 2017. World Bank.

[60]Yacoubian, H. A. (2018). Scientific literacy for democratic decision-making. International Journal of Science Education, 40(3), 308-327.

[61]Zeidler, D. L., Applebaum, S. M., \& Sadler, T. D. (2011). Enacting a socio-scientific issues classroom: Transformative transformations. In Socio-scientific issues in the classroom (pp. 277-305). Springer, Dordrecht. 